\title{
INDUSTRIAL ESTATE, FIRMS' PRODUCTIVITY, AND INTERNATIONAL TRADE RELATIONSHIP: THE CASE OF INDONESIAN MANUFACTURING FIRMS
}

\author{
Hubungan Kawasan Industri, Produktivitas Perusahaan, dan Perdagangan \\ Internasional: Studi Kasus Perusahaan Manufaktur Indonesia
}

\author{
Fitria Faradila ${ }^{1}$, MDNRVR Kakinaka ${ }^{2}$ \\ ${ }^{1}$ Trade Analysis and Development Agency, Ministry of Trade, Republic of Indonesia \\ JI. M. I. Ridwan Rais No. 5, Jakarta 10110, Indonesia \\ ${ }^{2}$ Graduate School for International Development and Cooperation, Hiroshima University, 1-3-2 \\ Kagamiyama, Higashi-Hiroshima City 739-8511, Japan \\ Email: faradilafitria@gmail.com
}

Naskah diterima: 25/11/2019; Naskah direvisi: 07/01/2020; Disetujui diterbitkan: 24/04/2020

Dipublikasikan online: 15/07/2020

\begin{abstract}
Abstrak
Kawasan industri diyakini dapat mendukung perkembangan sektor industri di negara berkembang melalui fasilitas infrastruktur yang lebih baik, akses ke industri pendukung serta limpahan teknologi dan informasi. Ketiga faktor tersebut diperkirakan dapat mendorong produktivitas dan aktivitas ekspor perusahaan manufaktur di dalam kawasan industri. Berbagai penelitian terdahulu masih memberikan hasil yang beragam mengenai hubungan ketiga variabel ini. Oleh karena itu, penelitian ini bertujuan untuk mengidentifikasi hubungan antara kawasan industri dengan tingkat produktivitas dan kegiatan ekspor pada studi kasus perusahaan manufaktur di Indonesia. Penelitian ini memperkenalkan penggunaan dari entropy balancing, salah satu teknik matching methods dengan unit analisis level data perusahaan. Perbedaan jumlah observasi yang cukup signifikan antara perusahaan di dalam dan di luar kawasan industri memotivasi penggunaan teknik matching methods agar data penelitian menjadi seimbang. Treatment (perlakuan) dari penelitian ini adalah ketika perusahaan berada di kawasan industri. Terdapat dua variabel keluaran yakni tingkat produktivitas dan aktivitas ekspor. Hasil penelitian menunjukkan bahwa berada di Kawasan Industri mendorong tingkat produktivitas, namun gagal untuk mempromosikan kegiatan ekspor.
\end{abstract}

Kata Kunci: Kawasan Industri, Produktivitas, Ekspor, Matching Methods, Entropy Balancing

\begin{abstract}
Many believe that the industrial estate could encourage the industrial sector in developing countries due to its better infrastructure, access to supporting industries, and the market as well as technology and information spillover. These factors could lead to a higher productivity level and export activities of manufacturing firms inside the industrial estate. Some previous studies still provide a mixed result regarding the relationship between these three variables. Thus, this paper contributes to the related study by examining the relationship between an industrial estate and both productivity level and export activity in the case of Indonesian Manufacturing Firms. The paper introduces the practice of entropy balancing, one of matching methods along with firm-level data as a unit of analysis. A significant difference in the number of observations between firms inside and outside the industrial estate motivates the usage of matching methods technique, so the data become balanced. The treatment is when the firms being in the industrial estate. There are two outcomes variables, which are productivity level and export activity. The result found that being industrial estate improves firms' productivity, yet it fails to promote export activity.
\end{abstract}

Keywords: Industrial Estate, Productivity, Export, Matching Methods, Entropy Balancing JEL Classification: L23, L52, L60 


\section{INTRODUCTION}

Lack of infrastructure, technology limitation, and asymmetric information is the main obstacle of doing business in developing countries. Giannecchi \& Taylor (2017) added that risk aversion and non investment friendly environments are often led to the inefficient industrial sector. Industrial estate helps developing countries to overcome these several business problems (UNIDO, 2012). As the centralization of industry activities, the industrial estate provides better infrastructure, access to the supporting industries and market, as well as technology and information spillover. Furthermore, Special Economic Zones (SEZ) or Export Processing Zone (EPZ), a specified industrial zone designed to promote export, has a series of location-specific advantages. By creating this zone, the nations send a signal for "open for business" and ready to deliver an excellent bureaucratic administration and finest infrastructure facility (Zhan \& Narula, 2019).

A successful industrial estate initially should be a tool for promoting regional industrial development (Lee et al., 2017). Because of that, it should answer the regional business problems. The site should match with the regional characteristics, environment, and development plan framework (UNIDO, 2012). Daddi et al. (2015) believed that there should be an intervention from a trade association and local government to optimize the benefit of the industrial estate, such as in Tuscany, Italy, in eco-industrial parks. Moreover, as the industrial estate is broadening, the new firms, including supplier firms, come in; thus, the transaction and production run smoothly. Generally, the industrial estate could accelerate the industrialization of developing countries. One of the crucial factors of industrialization in South Korea is by creating and renewing industrial estates 
in some regions, such as Daegu and Gumi (Hassink et al., 2018).

Many ASEAN countries have also applied industrial estate to support their economic condition. Thailand's government, through the Industrial Estate Authority of Thailand (IEAT), has stated the establishment of the industrial cluster since 1972 (Ditkaew and Pitchayatheeranart, 2019). The main goal of the cluster is to promote the competitiveness of the industrial sector in Thailand (Santipolvut \& Mali, 2015). Besides the industrial sector, the industrial cluster contributes to the growth of small and medium enterprises in Thailand (Santipolvut \& Mali, 2015; Turner et al., 2016). In the case of the Vietnam manufacturing sector, Gokan et al. (2019) claimed that the industrial cluster leads to productivity spillover among joined firms. The development of the area even has a positive impact on the innovation process in Vietnamese SME (Le, 2018).
The first initiative of the industrial estate in Indonesia was started in the 1970s by Home Affair Ministerial Decree no. 5 of the year 1974 and the establishment of Jakarta Industrial Estate Pulogadung (JIEP) in 1973. The goal is to support industrial growth, both in domestic and export activity. The government believes that there should be an integrated plan to encourage the industrial sector; thus, the industrial estate is created. The industrial estate is a center of industrial activity equipped with several infrastructure and facilities and managed by industrial estate company. In the regulation, the industrial estate company was limited to a state-owned company.

The regulations regarding the operations are changing over time. In 1989, the government changed the rule not only state-owned companies who can manage the site but also a private company. However, in 1996 the rule is revised as the government allowed the 
foreign company and joint venture between domestic and foreign to run the site.

The incentive of joining the industrial estate is regulated in Industry Ministerial Decree no. 291 of the year 1989. The regulation set some standards for the industrial estate, including maximum land use and necessary infrastructure, such as roads, water plants, power plants, drains, fire departments, wastewater management, etc. The government also provides a trade policy facility for a bonded zone, one kind of industrial estates, whose main goal is to promote export. The facilitations are reducing raw material import tariffs for the export-oriented firm and giving tax incentives. Atthahara \& Rizki (2019) believe that the development of industrial estate could be a growth center for Indonesia.

The role of industrial estate directly has a positive impact on Indonesia's regional economy, for example, in Batam City and Karawang District. The economic condition of the areas has been improving since the first development of the industrial estate. Napitupulu \& Nugroho (2016) stated there are a better citizen's economy and an increase in trade activity due to the higher industrial sector in Batam. The increasing growth of manufacturing sectors and improving the people's income are the direct positive effects of the industrial estate in Karawang (Atthahara \& Rizki, 2019). The industrial estate could also boost regional's potential commodity and product. Anam \& Setyawan (2019) stated that the industrial estate in Jepara District could encourage product innovation and export market access for wood products and the rattan craft industry.

Based on these factors, many believe that the industrial estate could encourage the industry sector by giving a higher productivity level (Santipolvut \& Mali, 2015; Nazarczuk, 2017). 
Besides the productivity level, the industrial estate also contributes to improving the region's added value, efficiency, and economic income. In the end, all these benefactions to the manufacturing industry lead to the acceleration of industrialization (Lee et al., 2017; Winardi et al., 2019).

Many studies that examined the relationship between an industrial estate and productivity. Nazarczuk (2017) presented the Special Economic Zone (SEZ) gives both directions related to the productivity level in the case of manufacturing firms in Poland. Firms who join SEZ more likely to have higher labor-oriented productivity yet lower capital productivity. There is a different characteristic between firms joining SEZ and not joining SEZ. Firms inside SEZ are mainly multinational companies who seek for cheaper labor input. Hashino \& Otsuka (2013) stated that industrial estate leads to technology, knowledge, and information spillover, so the firms within site gain a better productivity level. Winardi et al. (2017) show that there is a positive relationship between the industrial estate and manufacturing firms' performance in West Java Province, Indonesia. The firms inside the zone have a more significant multiplier effect of inputs than those outside the zone; hence, the joining firms give a higher output level.

Currently, research about the relationship between an industrial estate and international trade activity, mainly export, is still limited. Sabri et al. (2018) examined whether being in an industrial estate or not, gives a higher probability of Indonesian manufacturing firms to export. By using Regression Adjustment (RA) and InverseProbability-Weighted Regression Adjustment (IPWRA), their paper found firms inside the industrial estate are more likely to export than those outside the area. Then, the paper broadens its analysis by using probit regression to 
know the factors behind firms' decision to export. The firms' decision to export is mainly due to improved infrastructure, particularly water and power plants, as well as better fiscal incentives.

Nazarczuk \& Uminski (2018b) examined Poland's spatial openness to foreign trade through foreign ownership firms' activity and SEZ region instrument. Even though not directly analyzing the correlation between the economic zone and export activity, the paper showed that the foreign ownership status of the firms, together with being in SEZ, could effectively stimulate export.

Many believe that the industrial estate could encourage the industry sector by giving a higher productivity level (Hashino \& Otsuka, 2013; Santipolvut \& Mali, 2015; Nazarczuk, 2017). Santipolvut \& Mali (2015) stated the higher productivity is obtained from higher sales and less cost of production as well supported by technology and knowledge spillover that lead to innovation. Hashino \& Otsuka (2013) added that the cluster's productivity level would improve on the condition that the new entrance firm must-have new technology different from the incumbent firms.

Besides the productivity level, being the industrial estate could help the country to boost international trade activity, particularly export. Nazarczuk \& Uminski (2018b) stated that the industrial estate through Special Economic Zone (SEZ) lead to higher export. The study showed that the contribution of SEZs on total export reached approximately 24\% in 2013 . Sabri et al. (2018) identified in the case of Indonesia, being in industrial estate lead firms to do more export because of many incentives.

The industrial estate provides better infrastructure, access to supporting industries, and market as well as technology and information 
spillover. These factors could lead to a higher productivity level and export activities of manufacturing firms inside the industrial estate. Some previous studies still provide a mixed result regarding the relationship between these three variables. Many studies analyze the relationship between an industrial estate and productivity level, yet the study about its connection with export activity is still infrequent. The paper contributes to the related study by examining the relationship between an industrial estate and both productivity level and export activity in the case of Indonesian Manufacturing Firms. Thus, the objective is to analyze how the industrial estate relates to firms' productivity level and their export activity in Indonesia.

The paper introduces the practice of entropy balancing, one of matching methods, along with firm-level data as a unit of analysis of the paper is firm-level data. The treatment group is a bunch of firms being in the industrial estate, while the control group consists of firms outside the industrial estate. A huge gap in the number of observations between firms inside and outside the industrial estate may lead to covariates imbalance. Thus, the motivation of using the method is to create balanced samples for observational studies with binary treatment by reweighting the dataset to some target moments. There are two outcome variables, namely productivity level and export activity.

The paper is organized into five sections. The first section is the introduction, which explains the importance of establishing industrial estate, especially in developing countries, as well as the design of the paper. The second section is research methods that capture the paper's methodology, including initial calculation, methods, and data. Next are the result and discussion which is presented in section three. The last 
section is the conclusion of the study.

RESEARCH METHODS

The paper introduces the practice of entropy balancing, one of matching methods, to examine the relationship between being in an industrial estate and firms' productivity level and their export activity. The use of matching methods is intended to equalize the condition between the treatment and control group (King et al., 2016). Both groups have different initial conditions, so it is not entirely fair to compare these two groups. In this case, the treatment and control group are not randomly assigned, which means every board of the firm's organization could self-decided whether the firm will join the industrial estate or not.

The data are mainly obtained from the Survey of Indonesian Large and Medium Manufacturing Industry (Industry Besar dan Sedang/IBS), by the Statistics Indonesia (BPS). The database covers most of the data used in the paper.

Besides the IBS database, the paper also utilizes the tariff database from the World Integrated Trade Solution (WITS) World Bank. The length of the period is three years, from 2011 to 2013. Even though the year period of the research is three years, the STATA command for entropy balancing methods is not compatible with panel regression. Hence, the estimation is separated for each year; thus, the paper utilizes a cross-section approach. A cross-section approach is also intended to check the ATT consistency over the three-year period.

The unit of analysis of the paper is firm-level data. Based on the objective, the treatment is when the firms being in the industrial estate. There are two outcome variables, which are productivity level and export activity. The paper also considers the use of covariates variables: import tariff, characteristic of the firm itself, and 
location. Elliot \& Watson (2015) unit of analysis into two groups: the asserted that many survey data allow treatment group and the control group. generalization of the sample to the The treatment group is when a firm is population; thus, the analysis may be located inside the industrial estate. bias. In order to overcome the selection Hence, industrial estate is a binary bias from the observation, the paper variable that is one when the firms' applies entropy balancing, one of inside the industrial estate, zero matching methods. The entropy otherwise.

balancing urges the equalization of the

Only a few firms are joining the observation by simply reweighting the covariates among the groups (Elliot \& Watson, 2015).

\section{Treatment Variable}

Generally, the paper intends to examine how the industrial estate relates to firms' productivity level and their international trade activity by comparing firms inside and outside the industrial estate in Indonesia within the period of study (Table 1). The proportion is around $2 \%-4 \%$ of total observation. The big gap between the number of observations of the treatment and control group is one of the considerations of utilizing matching methods (Neuenkirch \& Neumeier, 2016).

site. The paper then categorizes the

Table 1. Summary of Number of Observations

\begin{tabular}{lccc}
\hline & 2011 & 2012 & 2013 \\
\hline Total & 3193 & 3065 & 3036 \\
Treatment & 127 & 98 & 72 \\
Control & 3066 & 2967 & 2964 \\
Proportion (\%) of Treatment & 3.98 & 3.20 & 2.37 \\
\hline
\end{tabular}

Source: Survey of Indonesian Large and Medium Manufacturing Industry (2019) 


\section{Outcome Variable}

The concept of productivity is related to firms' utilization of resources. Generally, productivity is defined as a ratio output to input. Hence, productivity improvement means enhanced effectiveness as well as improved the usage of available resources (Goshu et al., 2017). Ryzhenkov (2016) further explained that Total Factor Productivity (TFP) measures how effectively the input both human capital or labor and physical capital employed in the production process. Thum and Raciborski (2017) stated TFP gives a proper measurement of productivity level because it covers both the efficiency of input usage in production and technological progress, so that it can be seen as the only source of long-term growth.

The TFP is measured based on the Cobb-Douglas production function. Beveren (2012) specified the function as follows:

$$
Y_{i t}=A_{i t} K_{i t}^{\beta_{i t}} L_{i t}^{\beta_{1}} M_{i t}^{\beta_{\text {it }}}
$$

where $Y_{i t}$ indicates the total output of firm $i$ in period $t$ and a function of (i) ${ }^{A_{i t}}$, Hicksian neutral efficiency; (ii) $K_{i t}^{\beta_{k}}$, the input of fixed capital; (iii) $L_{i t}^{\beta_{t}}$, the input of labor; and (iv) $M_{i t}^{\beta_{m}}$, raw materials. It is difficult to measure the unobservable, ${ }^{A_{i t}}$, so when taking a natural log of the function, it becomes an intercept, $\beta_{0}$, or the firm's mean efficiency. Then, the function will be (lower case indicates natural logarithm form):

$$
y_{i t}=\beta_{0}+\beta_{k} k_{i t}+\beta_{1} l_{i t}+\beta_{m} m_{i t}+\varepsilon_{i t}
$$

The main problem of estimating production function is an unobservable factor that leads to productivity shock. Levinsohn \& Petrin (2003) argued that intermediate input should be a proxy of the unobserved factor. They believed the investment proxy could not be utilized because it would violate the monotonicity condition due to the firm 
reports zero investment. Thus, using the investment proxy may not be consistent.

Futhermore, Petrin et al. (2004) added that the production function covers the relationship between productivity shock and its input. If there is a positive productivity shock, firms will expand the output, and requiring more input. On the other hand, firms will decrease employing the input once there is a negative shock. Using input as a proxy will overcome the truncating of firms' zero investment.

\section{Following Levinsohn \& Petrin} (2003) and Beveren (2012), now the raw material variable is not exogeneous, but as a function of capital and productivity. The function is changed into:

$$
\begin{gathered}
y_{\text {it }}=\beta_{0}+\beta_{k} k_{i t}+\beta_{l} l_{i t}+\beta_{m} m_{i t}+\omega_{i t}+u_{\text {it }} \\
m_{i t}=m_{t}\left(k_{i t}, \omega_{i t}\right) \\
\omega_{i t}=\omega_{i t}\left(k_{i t}, m_{i t}\right) \\
y_{i t}=\beta_{0}+\beta_{k} k_{i t}+\beta_{l} l_{i t}+\beta_{m} m_{i t}+ \\
\omega_{i t}\left(k_{i t}, m_{i t}\right)+u_{i t}
\end{gathered}
$$

Using, Levinsohn \& Petrin (2003)

approach, the ${ }^{y_{i t}}$ as the logarithm of a firm's output could be calculated as revenue or value-added. The freely variable inputs are the logarithm of labor $\left({ }^{l_{\text {it }}}\right)$ and the logarithm of raw material $\left({ }^{m_{i t}}\right)$, while ${ }^{k_{\text {it }}}$ is the logarithm of state variable capital. The equation has two error components, ${ }^{\omega_{i t}}$ and ${ }^{u_{i t}}$. The paper is using estimation in the value-added case. Thus, $v_{i t}$ represents value-added, gross output minus input of intermediate or raw material. Now, only labor as a free variable input. The production function will be:

$$
\begin{aligned}
v_{i \mathrm{t}} & =\beta_{0}+\beta_{k} k_{\mathrm{it}}+\beta_{1} l_{\mathrm{it}}+\omega_{\mathrm{it}}+u_{\mathrm{it}} \\
& =\beta_{l} l_{\mathrm{it}}+\phi_{\mathrm{it}}\left(k_{\mathrm{it}}, m_{\mathrm{it}}\right)+u_{\mathrm{it}}
\end{aligned}
$$

Where

$$
\phi_{i \mathrm{t}}\left(k_{\mathrm{it}}, m_{\mathrm{it}}\right)=\beta_{0}+\beta_{k} k_{\mathrm{it}}+\omega_{\mathrm{it}}\left(k_{\mathrm{it}}, m_{\mathrm{it}}\right)
$$

Besides utilizing the TFP Levinsohn \& Petrin (2003) approach, 
the paper is also using physical productivity calculation. The physical productivity $\left(T F P Q_{i}\right)$ is a productivity measurement in terms of real output. The calculation follows Ryzhenkov (2016), which stated that physical productivity as a ratio of actual production to its input usage.

$$
T F P Q_{s i}=A_{s i}=k_{s} \frac{\left(P_{s i} Y_{s i}\right)^{\frac{\sigma}{\sigma-1}}}{K_{s i}^{a_{s i}} L_{s i}^{1-a_{s i}}}
$$

The paper also intends to capture the relationship between an industrial estate and firms' export activity. The proportion of export to total output indicates the export activity of the firms.

$$
\text { PRPREX }_{i}=\frac{\text { Export }_{i}}{\text { Output }_{i}}
$$

All the outcome variables are in the real value, which is already weighted by using the wholesale price index for each sector and consumer price index.

\section{Covariates}

Many variables influence firms' decision to join the industrial estate as well as the outcome variables: productivity and export activity. The paper applies tariff, firms' characteristics, and location as the covariates that might correlate both on treatment and outcome variables.

Many studies that examine the relationship between tariffs and productivity as well as export. Amiti \& Konings (2007) are the first to use both input and output tariffs to firms' productivity levels. Input tariffs are tariffs that are enacted to imported raw material, while output tariff is an import tariff on final goods. Reducing input tariffs will lower input purchasing from abroad, so the cost of production will be lower. The output tariff's impact on the firm is related to the competition with import of the final goods in the market. Reducing the output tariff could lead a stricter competition with final import 
goods so that it could drive higher productivity (Amiti \& Konings, 2007). Tariff reduction also happens to encourage export. Fan (2015) stated that a lower input tariff would lead to export quality improvement. Bas \& Strauss-Kahn (2015) stated further because of tariff cut on intermediate input; firms will raise their export price, especially when the inputs come from developed countries, and their final good market is also on high-income countries.

The measurement of input and output tariff follows Amiti \& Konings (2007). The output tariff will be calculated based on its HS 6-digit code from the concordance list of the Indonesian Industrial Code 2009. As a result, the tariff will only differ across the industry (k). Output tariff will be weighted average goods that are being produced by firm i. Since the code of specific goods data is challenging to find, so it is assumed that produced goods are the same as industry $\mathrm{k}$. Hence industry k can be seen as good that the firm produces.

Nevertheless, because of nonexistence firms' input level data, the paper utilizes a weighted average tariff instead that is varied across the industry (k) for using the input industry (j). The $w_{j k}$ is a cost proportion of industry $\mathrm{j}$ used to produce the good of firm $\mathrm{i}$ in industry $\mathrm{k}$.

$$
\text { input tarif } f_{t}^{k}=\sum_{j} w_{j k} \text { x output tariff } f_{t}^{j}
$$

$$
w_{j k}=\frac{\sum_{i} i_{i n p u t} t_{i j k}}{\sum_{i j} \text { input }_{i j k}}
$$

Other covariates are the firm's characteristics, including the location. The characteristics are (i) capital-labor ratio which indicates the capital intensity of the firm; (ii) ownership status, foreign, a binary variable ( 1 if the firm is a foreign company; 0 otherwise); (iii) size which is represented by the log of number of the workers; and (iv) 
average wage of the worker. Besides the firm's characteristics, the paper also considers the location of the firm. Jakarta is a location indicator. It is a binary variable, one if a firm is in Jakarta city and 0 otherwise.

\section{Entropy Balancing}

The condition of the treatment and control group sometimes not equal because it is not randomly assigned. Thus, looking up the causal relationship between the treatment and the outcome might be difficult. The outcome might correlate with some covariates that relate to the outcome variables. Meanwhile, the covariates may be imbalanced (Zhao \& Percival, 2016). The paper utilizes one of the matching methods approach, entropy balancing, to overcome the covariate imbalanced. Abadie \& Cattaneo (2018) believe that matching methods through covariates balancing would be one of the best methods for government project evaluation research.
Hainmuller (2011) stated entropy balancing is data preprocessing that employs a binary treatment. The method correctly overcomes imbalance by reweighting the unit of the covariate of the control group to match well with the one in the treatment group. The method's objective is to make the unit in the treatment and control group as close as possible. Zhao \& Percival (2016) added that entropy balancing is doubly robust as linear outcome regression is utilized. This technique also does not need a model to emphasize the treatment assignment.

The procedure of the paper follows Hainmuller \& Xu (2013). The treatment is a binary variable, one if unit $\mathrm{i}$ is attached to the treatment, while 0 is the unit $\mathrm{i}$ is in the control group. Hence, in the paper, the unit is one if a firm is being in the industrial estate and 0 for the firm outside the industrial estate or let $D_{i} \in\{1,0\}$. The potential outcome of 
being in the industrial estate is represented by $Y_{i}\left(D_{i}\right)$, so the total outcome of the observation is $Y=Y(1) D+(1-D) Y(0)$.

The goal is to find the effect of the treatment on the outcome variable, which is indicated by the Average Treatment Effect on the Treated (ATT). The ATT follows:

$$
\tau=E[Y(1) \mid D=1]-E[Y(0) \mid D=1]
$$

Where $\quad E[Y(0) \mid D=1]$ is a counterfactual, the expected outcome of the treated observation without given treatment, as the main specification of entropy balancing, the distribution of the covariates needs to be balanced so that it can be matched with those in the treatment group. The balancing procedure is employing a weighting approach by assessing the weight in the estimated counterfactual:

$$
E[Y(\widehat{0})] \bar{D}=1]=\frac{\sum_{[\mathrm{i} \mid D=0\}} Y_{i} w_{i}}{\sum_{\{i[D=0\}} W_{i}}
$$

The weight's usage is to make the covariates between the treatment and control variable as close as possible. Thus, the target is to minimize the entropy distance among the groups.

$$
\min _{w_{i}} H(w)=\sum_{\{i=0\}} w_{i} \log \left(\frac{w_{i}}{q_{i}}\right)
$$

With the constrains:

$$
\sum_{[i \mid[D=0\}} w_{i} C_{r i}\left(X_{i}\right)=m_{r} \text { with } r \in 1_{s \ldots .} R
$$

$$
\sum_{[i] D=0\}} w_{i}=1
$$

$w_{i} \geq 0$ for all $i$ such that $D=0$

The $C_{r i}\left(X_{i}\right)=m_{r r}$ means a set of R balance constraints enacted to covariate the moment of the reweighting control group. There are there moments of the covariate distribution, given as the mean (first moment), the variance (second moment), and the skewness (third moment). The paper only uses the first moment of the covariate distribution. 


\section{Descriptive Analysis}

The difference between the treatment group and the control group is quite noticeable based on their average value of outcome variables (Table 2). The outcome variables in the treatment group are more significant than in the control group. The treatment group has approximately $12 \%$ higher TFP points than the control group. The same condition is also reflected in export variables, where the average proportion of export in the treatment group (27.2\%) is bigger than those in the control group $(12.7 \%)$.

The difference also happens in covariates variables, yet the comparison is mixed. For the tariff variable, the treatment group seems to have a lower tariff than the control group. The condition is reasonable because of the privilege of tariff reduction in the industrial estate. Usually, firms inside the zone have a high dependency on importing and exporting goods. Therefore, an authority sometimes gives a free import tariff to support their business activity (Moberg, 2018). For the firms' characteristics, such as ratio capital to labor, the number of workers, and the average wage, the values of the treatment group are also bigger than those of the control group. Due to incoming investment, the ratio capital to labor is higher in the zone through technology spillover (Lu et al., 2017).

The firms inside the industrial zones also tend to pay higher wages since they applied a good regulation of employment, including working hours, safety and health, and overtime fee (Cirera \& Lakshman, 2017; Thanh et al, 2018). Foreign firms are also more likely to choose industrial estate as a production base. One of the reasons is to link between global connectedness and local innovation performance 
(Turkina \& Assche, 2018). While Puig et

foreign investment usually pick a

al. (2019) assumed that the MNEs' location with strategic characteristics.

Table 2. Summary of Statistics

\begin{tabular}{lrrlrr}
\hline & \multicolumn{4}{c}{ Covariates } \\
\hline \multicolumn{1}{c}{ Variables } & Treatment & Control & \multicolumn{1}{c}{ Variables } & Treatment & Control \\
\hline TFP & 9.041 & 8.037 & Output Tariff & 7.349 & 8.313 \\
TFPQ & 8.039 & 7.136 & Input Tariff & 5.982 & 6.201 \\
Proportion of Export & 0.272 & 0.127 & Capital Labor Ratio & 26.697 & 21.563 \\
& & & Foreign & 0.3 & 0.03 \\
& & & Log number of workers & 4.599 & 3.929 \\
& & & Average Wage & $33,929.51$ & $18,493.06$ \\
& & & Jakarta & 0.051 & 0.039 \\
\hline
\end{tabular}

Source: Processed from the results of Survey of Indonesian Large and Medium Manufacturing Industry BPS and WITS World Bank (2019)

\section{RESULT}

\section{Result on Entropy Balancing}

By using weight, entropy balancing marks balanced covariates between the treatment and control group. Thus, the analysis could capture the treatment effect when the observation is balanced. Before balancing, the difference in covariates between treatment and control group seems noticeable.

Table 3 shows that the output tariff in the treatment group, in most cases, is lower than the control group. The output tariff in the treatment group ranges from $6 \%$ to $7 \%$, while the control groups have a slightly higher value (around $8 \%$ ). Unlike the output tariff, the gap of input tariff in both groups quite invisible. The tendency of lower tariffs in the industrial estate is normal because some industrial estates, particularly bonded zone, providing lower tariffs for firms inside the zone.

Firms inside industrial estate are also more capital-intensive oriented (Table 3). The higher value of the capital-labor ratio in industrial estate 
means firms inside the site use more capital than those outside the industrial estate, except for 2011. At the time, the Ministry of Industry (2011) enacted the National Industrial Policy, which focuses on several priority manufacturing industries. Hence, many investments came to the manufacturing industry. Since more firms are located outside the industrial estate, the policy's impact seems noticeable in the control group.

Table 3. Covariates Before and After Balancing

\begin{tabular}{lrrrrrr}
\hline & \multicolumn{2}{c}{ Year: 2011 } & \multicolumn{2}{c}{ Year: 2012 } & \multicolumn{2}{c}{ Year: 2013 } \\
\hline & Treatment & Control & Treatment & Control & Treatment & Control \\
\hline Observations & 127 & 3066 & 98 & 2967 & 72 & 2964 \\
\hline Before (without weighting) & & & & & & \\
Output Tariff & 7.77 & 8.164 & 7.23 & 8.295 & 6.77 & 8.487 \\
Input Tariff & 6.045 & 6.488 & 6.269 & 6.229 & 5.482 & 5.875 \\
Capital Labor Ratio & 30.68 & 53.62 & 36.29 & 5.253 & 6.616 & 4.726 \\
Foreign & 0.291 & 0.028 & 0.316 & 0.029 & 0.292 & 0.031 \\
Log number of workers & 4.68 & 3.93 & 4.557 & 3.934 & 4.513 & 3.923 \\
Average Wage & 35,259 & 12,776 & 32,612 & 22,696 & 33,378 & 20,200 \\
Jakarta & 0.055 & 0.036 & 0.041 & 0.04 & 0.056 & 0.040 \\
\hline After: _webal as the weighting variable & & & & & \\
Output Tariff & 7.77 & 7.77 & 7.23 & 7.231 & 6.77 & 6.772 \\
Input Tariff & 6.045 & 6.045 & 6.269 & 6.269 & 5.482 & 5.483 \\
Capital Labor Ratio & 30.68 & 30.7 & 36.29 & 36.27 & 6.616 & 6.614 \\
Foreign & 0.291 & 0.291 & 0.316 & 0.316 & 0.292 & 0.292 \\
Log number of workers & 4.68 & 4.68 & 4.557 & 4.557 & 4.513 & 4.513 \\
Average Wage & 35,259 & 35,250 & 32,612 & 32,610 & 33,378 & 33,374 \\
Jakarta & 0.055 & 0.055 & 0.041 & 0.041 & 0.056 & 0.055 \\
\hline
\end{tabular}

Source: STATA Result (2019)

However, in 2013, the gap in inside industrial estate is bigger - the capital intensity started to diminish. average wage of firms inside industry Likewise, the size of the firm, which is estate is larger than that of those signified by the number of workers outside the site. Many foreign 
companies prefer operating in the productivity level by approximately industrial estate and many 27-67\%. In 2011, the coefficient of TFP manufacturing firms in the industrial using Levinsohn Petrin was higher than estate in Jakarta (Table 3).

physical TFP. However, in general, the

The results show that the control group's reweighting covariates have adjusted to the treatment group after balancing. Thus, the mean value of the control group's is covariates almost the same as in the treatment group. Next, the paper estimates the balanced observations by using simple Ordinary Least Square (OLS).

\section{Estimation Result on Productivity}

The OLS estimation is applying a cross-section approach for each year to check its consistency. The estimation result shows that being in the industrial estate is associated with a higher ATT in physical TFP (TFPQ) is bigger. In 2012, the ATT on both TFP measurements reach their peak of almost $70 \%$ increased. However, in 2013, the ATT went down.

The result is consistent with Nazarczuk (2017) and Winardi et al. (2017), where firms' inside the industrial estate are more likely to have a better productivity level due to higher efficiency. Hashino \& Otsuka (2013) stated that efficiency comes from technology, knowledge, information spillover and its closeness with the supplier industry.

Table 4. The ATT on Productivity Level

\begin{tabular}{llll}
\hline \multirow{2}{*}{ Outcome } & \multicolumn{3}{c}{ Matching Methods: Entropy Balancing } \\
\cline { 2 - 4 } & $\mathbf{2 0 1 1}$ & $\mathbf{2 0 1 2}$ & $\mathbf{2 0 1 3}$ \\
\hline TFP & $0.34857^{* * *}$ & $0.49059^{* * *}$ & $0.36579^{* * *}$ \\
TFPQ & $0.26507^{* * *}$ & $0.66766^{* * *}$ & $0.43748^{\star * *}$ \\
\hline
\end{tabular}

Source: STATA Result (2019) 
Winardi et al. (2017) pointed out that there are two vital benefits of the industrial estate to the firms. First, location benefit, where the firm could save more cost due to its closeness to the supporting industries. Second, urbanization advantage is because the industrial estate company already provides the basic infrastructure that is beneficial to the production process. The additional result of the estimation shows foreign firms more likely to choose the industrial estate as the production site. This led to a higher productivity level since there is knowledge spillover through technology transfer as an FDI arises (Djulius, 2017). Conclusively, this higher productivity level of the manufacturing sector will overcome the deindustrialization issue in Indonesia (Winardi et al., 2017).

\section{Estimation Result on Export Activity}

Unlike its relationship with productivity level, being in industrial estate fails to promote export activity. Based on the result, the coefficient is insignificant for all years. The result is opposite to Sabri et al. (2018), showing that being in industrial estate increases dirms' probability of exporting.

Our different results may due to the differences in covariates or control variables being used. Sabri et al. (2018) utilized several other explanatory variables: distance to the port, fiscal incentives, and seaport capacity. However, because of data limitations, our current study could not consider all these factors. Further research could be undertaken to enrich this study by considering other variables. 
Table 5. The ATT on Export Activity

\begin{tabular}{lccc}
\hline \multirow{2}{*}{ Outcome } & \multicolumn{3}{c}{ Matching Methods: Entropy Balancing } \\
\cline { 2 - 4 } & $\mathbf{2 0 1 1}$ & $\mathbf{2 0 1 2}$ & $\mathbf{2 0 1 3}$ \\
\hline Export & 0.01961 & -0.00794 & -0.00662 \\
\hline
\end{tabular}

Source: STATA Result (2019)

Centre for Strategic and Nazarczuk \& Uminski (2018a) International Studies (2015) stated stated that the role of an industrial many obstacles that hold up the estate on international trade seems potential gain of export from the higher on import activity than export. industrial estate, particularly the bonded The higher number of foreign zone. One of the reasons is the companies is usually linked to the company's unwillingness to export, global value chain, which allows them to which was ordered by the government. acquire raw materials from abroad.

Based on Ministry of Finance Decree No. 255 of the Year 2011, firms inside the bonded zone should trade in their $75 \%$ output to abroad (then revised to $50 \%$ in 2013). However, the average export proportion of firms inside the industrial estate is only $27,2 \%$. Indonesia is a big size country with a huge population. Undoubtedly, the consumption portion was high, even reach around 55\% of total GDP in 2018 . Furthermore, due to its growing demand, the domestic market is still potential.
CONCLUSION AND POLICY RECOMMENDATION

The goal of establishing industrial estate in Indonesia is to support industrial growth by improving the productivity level and promoting industrial trade, mainly export. The result found that industrial estate improves manufacturing firms; however, it does not provide support to the view that industrial estate promotes export activities of firms. Based on the result, the coefficient is insignificant for all 
years. It is projected that growing demand in Indonesia causes manufacturing firms still want to focus on the domestic market, instead of the foreign market.

The data stated that the average export proportion of firms inside the industrial estate counts as $27,2 \%$, much lower than the government target of $75 \%$ (then revised to be $50 \%$ ). Hence, to optimize promoting exports from the industrial estate, the central authority should focus on the development of the bonded zone or free trade zone of the area as well as improve supervision so that companies could comply with the rules.

\section{ACKNOWLEDGEMENT}

We would like to express our grateful appreciation to Prof. Ichihashi Masaru and Assoc. Prof. Takahashi Shingo for the beneficial insight of the paper. We thankfully appreciate to all 'Sensei's and staffs in Graduate School for International Development and
Cooperation (IDEC) of Hiroshima University. We also would like to thank the lecturers as well as staffs in the Graduate Program of Economics (PPIE) of Universitas Indonesia. Furthermore, we especially sincerely thanks to Indonesia Ministry of National Development Planning (BAPPENAS) who provide the scholarship during the study.

\section{REFERENCES}

Abadie, A. \& Cattaneo, M. D. (2018). Econometrics Methods for Program Evaluation. The Annual Review of Economics 10:465-503.

Amiti, M. \& Konings, J. (2007). Trade Liberalization, Intermediate Inputs and Productivity: Evidence from Indonesia. American Economic Review 97(5):1611-1638.

Anam, A. K. \& Setyawan, M. (2019). Strategi Pengembangan Produk Unggulan Daerah Berbasis Klaster pada Sentra Kawasan Industri Rotan di Kabupaten Jepara. Management Development and Applied Research Journal 1(2): 1-8.

Atthahara, H. \& Rizki, M. F. (2019). Analisis tentang Rencana Tata Ruang Wilayah dan Dampak Kebijakan Pengembangan Kawasan Industri bagi Masyarakat Sekitar di Kabupaten Karawang. The Indonesian Journal of Politics and Policy 1(1): 9-21.

Bas, M. \& Strauss-Kahn, V. (2015). Input-trade Liberalization, Export Prices and Quality Upgrading. 
Journal of International Economics 95:250-262.

Beveren, I. V. (2012). Total Factor Productivity Estimation: A Practical Review. Journal of Economic Survey 22(1):98-128.

Cirera, X., Lakshman, R. W. D. (2017). The Impact of Export Processing Zones on Employment, Wages and Labour Conditions in Developing Countries. Journal of Development Effectiveness, 9(3).

CSIS. (2015). Kawasan Ekonomi Khusus dan Strategi di Indonesia: Tinjauan atas Peluang dan Permasalahan. Retrieve on 28 November 2019 from https://www.csis.or.id/

Daddi, T., Iraldo, F., Frey, M., Gallo, P., Gianfrate, V. (2015). Regional policies and eco-industrial development: the voluntary environmental certification scheme of the eco-industrial parks in Tuscany (Italy). Journal of Cleaner Production, 1-9.

Ditkaew, K. \& Pitchayatheeranart, L. (2019). Using Structure Equation Model for Evaluating the Impact of Activity Based Costing towards Strategic Management Innovation and Performance of Firms in Industrial Estate Authority of Thailand. Asian Administration and Management Review 2(1):110-121.

Djulius, H. (2017). Foreign Direct Investment and Technology Transfer: Knowledge Spillover in the Manufacturing Sector in Indonesia. Global Business Review 18(1):57-70.

Elliot, M. \& Watson, S. K. (2015). Entropy Balancing: A Maximum-entropy Reweighting Scheme to Adjust for Coverage Error. Quality \& Quantity 22(4):1781-1797.

Fan, H., Li, Y. A., Yeaple, S. R. (2015). Trade Liberalization, Quality and Export Prices. The Review of Economics and Statistics, Vol. 97(5):
1033-1051.

Giannecchini, P., Taylor, I. (2017). The Eastern Industrial Zone in Ethiopia: Catalyst for Development?. Geoforum, 88: 28-35.

Gokan, T., Kuroiwa, I., Nakajima, K. (2019). Agglomeration economies in Vietnam: A firm-level analysis. Journal of Asian Economics 62: 52-64.

Goshu, Y. Y., Kitaw, D., Matebu, A. (2017). Development of Productivity Measurement and Analysis Framework for Manufacturing Companies. Journal of Optimization in Industrial Engineering 22: 1-13.

Hainmuller, J. (2011). Entropy Balancing for Causal Effects: A Multivariate Reweighting Method to Produce Balanced Samples in Observational Studies. Political Analysis 20: 25-46.

Hainmuller, J. \& Xu, Y. (2013). Ebalance: A Stata Package for Entropy Balancing. Journal of Statistical Software 54(7).

Hashino, T. \& Otsuka, K. (2013). Cluster-based Industrial Development in Contemporary Developing Countries and Modern Japanese Economic History. Journal of The Japanese and International Economies 30: 19-32.

Hassink, R., Hu, X., Shin, D., Yamamura, S., Gong, H. (2018). The Restucturing of Old Industrial Areas in East Asia. Area Development and Policy 3(2): 185-202.

King, G., Lucas, C., Nielsen, R. A. (2016). The Balance-Sample Size Frontier in Matching Methods for Causal Inference. American Journal of Political Science 61(2): 473-489.

Le, V. A. (2018). Does Agglomeration Account for Process Innovation in Vietnamese Small and Medium Enterprises?. Economics Honors Projects 83.

Lee, S. J., Lin, G. T. R., His, P. H. (2017). 
Industrial Cluster Development and Its Contribution to Economic Growth in Taiwan - Hsinchu Science and Industrial Park (HSIP). Journal of Scientific \& Industrial Research 76: 273:278.

Levinsohn, J. \& Petrin, A. (2003). Estimating Production Function using Inputs to Control for Unobservables. Review of Economic Studies 70: 317-341.

Lu, Y., Tao, Z., Zhu, L. (2017). Identifying FDI spillover. Journal of International Economics, 107: 75-90.

Moberg, L. (2018). The Political Economy of Special Economic Zones: Lesson for the United States. Chapman Law Review 21(2).

Napitupulu, B. K. \& Nugroho, P. (2016). Pengaruh Aktivitas Industri terhadap Peningkatan Ekonomi Penduduk dan Perkembangan Perdagangan dan Jasa di Kota Batam. Teknik Perencanaan Wilayah Kota 5(1): 1-9.

Nazarczuk, J. M. (2017). Do operations in SEZs improve a firm's productivity? Evidence from Poland. New Trends and Issues Proceedings on Humanities and Social Sciences 4(10): 256-264.

Nazarczuk, J. M. \& Uminski, S. (2018a). The geography of openness to foreign trade in Poland: The role of special economic zones and foreign-owned entities. Bulletin of Geography. Socio-economic Series, 39(39): 97-111.

Nazarczuk, J. M. \& Uminski, S. (2018b). The Impact of Special Economic Zones on Export Behaviour: Evidence from Polish Firm-level Data. Ekonomie Vol. 21(3): 4-22.

Neuenkirch, M., Neumeier, F. (2016). The impact of US sanction on Poverty. Journal of Development Economics 121: 110-119.

Petrin, A., Poi, B. P., Levinsohn, J. (2004).
Production Function Estimation in Stata using Inputs to Control for Unobservables. The Stata Journal 4(2): 113-123.

Puig, F., Madhok, A., Shen, Z. (2019). Investigating Firm Heterogeneity in Country-of-origin Cluster Location Choice Decisions. Multinational Business Review.

Ryzhenkov, M. (2016). Resource Misallocation and Manufacturing Productivity: The Case of Ukraine. Journal of Comparative Economics 44: 41-55.

Sabri, M., Nachrowi, D. N., Soetjipto, W., Panennungi, M. A. (2018). Industrial Estate and Export Decision of Manufacturing Firms in Indonesia. Malaysian Journal of Economic Studies 55(2): 189-207.

Santipolvut, S. \& Mali, K. (2015). Industrial Cluster Development in Thailand: There is still a Long Road Ahead. Journal of Applied Economic Sciences 8(38): 1259-1287.

Thanh, N. T., Lebailly, P., Dien, N. T. (2018). Migrant Workers for the Development of Industrial Zones in Bac Ninh Province, Vietnam. Asian Social Science 14(12): 115-123.

Thum, A. E. \& Raciborski, R. (2017). Determinants of Trend TFP Growth and Key Policies that Influence It. Quarterly Report on The Euro Area 16(2): 31-41.

Turkina, E. \& Assche, A. V. (2018). Global Connectedness and Local Innovation in Industrial Clusters. Journal of International Business Studies 49: 706-728.

Turner, M., Sermcheep, S., Anantasirijikat, S., Srisangnam, P. (2016). Small and medium-sized enterprises in Thailand: government policy and economic development. Asia Pacific Journal of Public Administration 38(4): 251-269. 
United Nations Industrial Development Organization. (2012). Conference Report on Europe and Central Asia Regional Conference on Industrial Parks: as a tool to foster local industrial development, Baku, Azerbaijan, April 17-18, 2012. UNIDO press.

Winardi., Priyarsono, D. S., Siregar, H., Kustanto, H. (2017). Kinerja Sektor Industri Manufaktur Provinsi Jawa Barat Berdasarkan Lokasi di Dalam dan di Luar Kawasan Industri. Jurnal Manajemen Teknologi 16(3): 241-257.
Winardi., Priyarsono, D. S., Siregar, H., Kustanto, H. (2019). Peranan Kawasan Industri dalam Mengatasi Gejala Deindustrialisasi. Jurnal Ekonomi dan Pembangunan Indonesia, 19(1): 84-95.

Zhan, J. \& Narula, R. (2019). Using Special Economic Zones to Facilitate Development: Policy Implications. Transnational Corporations 26(2): 1-25.

Zhao, Q. \& Percival, D. (2016). Entropy Balancing is Doubly Robust. Journal of Causal Inference 5(1). 
